\title{
Assessment of the Optimal Anaesthesia Technique for Caesarean Section and Clinical Effects on Mothers and Newborns
}

\section{Sezaryen için Optimal Anestezi Tekniğinin Değerlendirilmesi, Anne ve Yenidoğan Üzerine Etkileri}

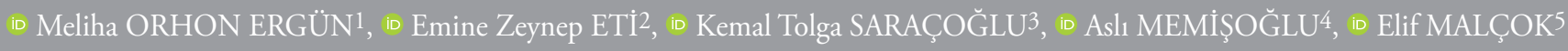

${ }^{1}$ Marmara University Pendik Training and Research Hospital, Clinic of Anesthesiology and Reanimation, İstanbul, Turkey

${ }^{2}$ Marmara University Hospital, Clinic of Anesthesiology and Reanimation, İstanbul, Turkey

${ }^{3}$ Kartal Training and Research Hopital, Clinic of Anesthesiology and Reanimation, İstanbul, Turkey

${ }^{4}$ Marmara Universiy Hospital, Clinic of Pediatri, İstanbul, Turkey

5Marmara University Pendik Training and Research Hospital, Clinic of Gynecology and Obstetrics, İstanbul, Turkey

\begin{abstract}
Objective: Regional anaesthesia is mostly preferred for elective caesarean delivery. This study aimed to compare general, epidural and spinal anaesthesia techniques in terms of their foetal and maternal effects.

Methods: Parturients undergoing elective caesarean delivery were randomly divided into three groups: general anaesthesia (GA), epidural anaesthesia (EA), and spinal anaesthesia (SA). The APGAR score, foetal blood gas level, free $\mathrm{O}_{2}$ requirement and positivepressure ventilation, phototherapy requirement, bilirubin level and weight loss were recorded. The time to the first breastfeeding, perioperative bleeding, crystalloid requirement, ephedrine consumption, first analgesic requirement, the time of defaecation and mobilization were also measured.

Results: The APGAR scores and $\mathrm{SpO}_{2}$ were lower in the GA group $(\mathrm{p}<0.05)$. Six newborns required $\mathrm{O}_{2}$ supply and positive-pressure ventilation and one newborn from the GA group was intubated and transferred to the NICU. The time to first breastfeeding was prolonged in the GA group compared with the other groups $(\mathrm{p}<0.05)$. Postnatal 48 -hour weight loss of the newborns was higher in the $E A$ and $S A$ groups than in the GA group $(p<0.05)$. Peropertive
\end{abstract}

\section{ÖZ}

Amaç: Sezaryen ile doğumlarda rejyonal anestezi çoğunlukla tercih edilir. Bu çalışmada genel, epidural ve spinal anestezi tekniklerinin fetal ve maternal etkileri açısından karşılaştırılması amaçlandı

Yöntemler: Sezaryen ile doğum yapan gebeler rastgele üç gruba ayrıldı: genel anestezi (GA), epidural anestezi (EA) ve spinal anestezi (SA). APGAR skoru, fetal kan gazı seviyesi, serbest $\mathrm{O}_{2}$ gereksinimi ve pozitif basınçlı ventilasyon, fototerapi gereksinimi, bilirubin seviyesi ve kilo kaybı kaydedildi. Ayrıca ilk emzirme zamanı, perioperatif kanama, kristalloid gereksinimi, efedrin tüketimi, ilk analjezik gereksinimi, ilk defekasyon ve mobilizasyon süresi ölçüldü.

Bulgular: APGAR skorları ve $\mathrm{SpO}_{2}$ GA grubunda düşüktü $(\mathrm{p}<0,05)$. Altı yenidoğanda $\mathrm{O}_{2}$ desteği ve pozitif basınçlı ventilasyon gerekti ve GA grubundan bir yenidoğan entübe edildi ve NICU'ya transfer edildi. İlk emzirme zamanı GA grubunda diğer gruplara göre uzadı $(\mathrm{p}<0,05)$. Yenidoğanların doğum sonrası 48 saatlik kilo kaybı EA ve $S A$ gruplarında GA grubundan daha yüksekti $(\mathrm{p}<0,05)$. Peropertif kanama GA grubunda daha yüksekti. SA grubunda, efedrin ve sıvı gereksinimleri daha yüksekti ve mobilizasyon süresi daha kısa idi $(\mathrm{p}<0,05)$. İlk analjezik gereksinimi ve ilk defekasyon süresi EA grubunda daha kısaydı $(\mathrm{p}<0,05)$.
Address for Correspondence: Meliha ORHON ERGÜN, Marmara University Pendik Training and Research Hospital, Clinic of Anesthesiology and Reanimation, İstanbul, Turkey

E-mail: dr.meliha@gmail.com ORCID ID: orcid.org/0000-0001-8158-1393
Received: 17.12 .2019

Accepted: 13.09 .2019

Cite this article as: Orhon Ergün M, Eti EZ, Saraçoğlu KT, Memişoğlu A, Malçok E. Assessment of the Optimal Anaesthesia Technique for Caesarean Section and Clinical Effects on Mothers and Newborns. Bezmialem Science 2020;8(4):411-417. 
bleeding was higher in the GA group. In the SA group, ephedrine and fluid requirements were higher and the mobilization time was shorter $(\mathrm{p}<0.05)$. The first analgesic requirement and defaecation time were shorter in the EA group $(\mathrm{p}<0.05)$.

Conclusion: With general anaesthesia, there are lower APGAR scores, a requirement for a free $\mathrm{O}_{2}$ supply and more frequent positivepressure ventilation and a longer time to the first breastfeeding compared to those with regional anaesthesia. Therefore, regional techniques are preferable for caesarean delivery.

Keywords: General anaesthesia, regional anaesthesia, obstetric anesthesia, anaesthesia techniques on clinical effects
Sonuç: Genel anestezi ile, daha düşük APGAR skorları, serbest $\mathrm{O}_{2}$ gereksinimi ve daha sık pozitif basınçlı ventilasyon gereksinimi ve ilk emzirme zamanı rejyonel anestezi ile karşılaştırıldığında daha uzundu. Bu nedenle sezaryen ile doğumda rejyonel teknikler tercih edilebilir.

Anahtar Sözcükler: Genel anestezi, rejyonal anestezi, obstetrik anestezi, anestezi tekniklerinin klinik etkileri

\section{Introduction}

Regional anaesthesia is preferred for caesarean delivery to avoid maternal risks of general anaesthesia (GA) (1). Despite the apparent advantages regarding maternal safety, the effects on the foetus remain controversial. As a result of an acute reduction in uteroplacental blood flow, spinal anaesthesia (SA) may lead to foetal acidosis, hypoxia or low Apgar scores $(2,3)$. Evidence that the effects of drugs in GA affect neonatal neurological consequences (7) continues to increase. The influence of anaesthetic drugs on growing new brain cells has become a considerable concern. Recently, both the apoptotic properties of volatile agents have been reported $(10,11)$.

This study aimed to compare general, epidural and SA techniques regarding their maternal and foetal effects. The primary outcome of the study was to evaluate the effect of the anaesthesia technique on the Apgar score, foetal acidosis and the need for respiratory support in newborns. The secondary outcome was to compare the time until the first breastfeeding.

\section{Method}

The Ethics Committee approved the study (B104ISM4340029-1009-90) and written informed consent was obtained. The clinical trial number is ACTRN12618002051224. Seventy-five ASA II parturient females undergoing caesarean section for their first delivery and in their $38^{\text {th }}$ week of pregnancy were included. The exclusion criteria were endocrine, cardiopulmonary, renal, hepatic or neuromuscular diseases; preeclampsia; or known foetal abnormalities, including growth retardation, umbilical artery anomalies or malposition. Patients were randomly divided into three groups $(n=25)$ : GA, epidural anaesthesia (EA) and SA. The randomisation was performed using sequentially numbered, opaque sealed envelopes.

In the GA group, patients received $5 \mathrm{mg} / \mathrm{kg}$ thiopental sodium and $0.6 \mathrm{mg} / \mathrm{kg}$ rocuronium bromide iv for induction of anaesthesia. After the patients were intubated, anaesthesia was maintained with $30 \% \mathrm{O}_{2}, 70 \% \mathrm{~N}_{2} \mathrm{O}$ and $1 \%-2 \%$ sevoflurane. Patients were ventilated with $100 \% \mathrm{O}_{2}$ during the period between the placement of the bladder retractor and cord clamping after delivery. The neuromuscular block was antagonised with 0.03$0.07 \mathrm{mg} / \mathrm{kg}$ neostigmine and $0.02 \mathrm{mg} / \mathrm{kg}$ iv atropine sulphate.
Patients in the EA group were administered $16 \mathrm{~mL}$ of $0.5 \%$ bupivacaine $+3 \mathrm{mg}$ morphine while lying in the lateral position through the L4-L5 intervertebral space using an $18 \mathrm{G}$ Touhy needle as identified by the loss of resistance technique. An epidural catheter was left $5 \mathrm{~cm}$ in the epidural space.

In the SA group, $3 \mathrm{~mL}$ of $0.5 \%$ heavy bupivacaine was injected with $200 \mu \mathrm{g}$ of morphine through the L4-L5 intervertebral space by a $25 \mathrm{G}$ spinal needle (Quincke) in the lateral decubitus position. In Groups EA and SA, surgery was started by the time the sensory block reached the T4 dermatome. The level of sensory block was assessed by the "Pinprick" test. Motor block was assessed using the Bromage scale.

The mean arterial pressure (MAP), heart rate (HR) and $\mathrm{SpO}_{2}$ values were recorded before and after anaesthesia induction and at the $1^{\text {st }}, 5^{\text {th }}, 10^{\text {th }}, 20^{\text {th }}$ and $40^{\text {th }}$ minute after the surgical incision. A decrease in HR below $30 \%$ of basal values was considered bradycardia, and $0.5 \mathrm{mg}$ of atropine was administered. When the MAP showed a decrease of more than $30 \%$, it was regarded as hypotension, and $10 \mathrm{mg}$ of ephedrine was injected iv as a bolus dose.

The skin-uterine incision time, uterine-incision delivery time, perioperative bleeding, crystalloid requirement and the total amount of iv ephedrine required were recorded. The time of defaecation and mobilisation, discharge of the mother and the time to first breastfeeding from delivery of the newborn were also recorded.

The time when the postoperative pain score (according to the Numeric Rating Scale (NRS), $0=$ no pain, $10=$ extreme pain) increased by 3 or more was recorded as the first analgesia requirement time. The GA and SA groups were administered $1 \mathrm{mg} / \mathrm{kg}$ meperidine iv every 6 hours and $1 \mathrm{~g}$ of paracetamol iv every 8 hours. The EA group received a mixture of $3 \mathrm{mg}$ of morphine and $15 \mathrm{mg}$ of bupivacaine in a volume of $9 \mathrm{cc}$ through the epidural catheter.

A paediatrician examined the newborns. They were monitored, and their $\mathrm{SpO}_{2}$ and Apgar scores were recorded at the $1^{\text {st }}, 5^{\text {th }}$ and $10^{\text {th }}$ minute. The blood gas level obtained from the umbilical vein was examined. In the postoperative period, the time to first breastfeeding; phototherapy requirement, level of bilirubin, 
weight loss of the newborn at the $24^{\text {th }}$ and $48^{\text {th }}$ hour, and need at birth for free $\mathrm{O}_{2}$, positive-pressure ventilation (PPV), chest compressions, intubation and intensive care admission were also recorded.

\section{Statistical Analysis}

The SPSS programme version 21.0 was used for the statistical analyses. Descriptive statistics of the data were expressed as the mean, standard deviation, median, minimum, maximum, rate and frequency values. The distribution of variables was examined using the Kolmogorov-Smirnov test. While quantitative data were analysed with ANOVA (Tukey test) and Kruskal-Wallis (Mann-Whitney U test), qualitative data were assessed primarily with the chi-square test. Fisher's exact test was used to analyse the qualitative data when the conditions required for the chi-square test were not met. A value of $\mathrm{p}<0.05$ was used for a significant difference. The sample size was based on preliminary clinical observations of the Apgar scores. The power of our study was determined to be $90 \%$ with $5 \%$ error and a standard effect size of 1.28.

\section{Results}

No subjects were excluded from the study. The demographic data of the patients were comparable in the study groups $(\mathrm{p}>0.05)$ (Table 1). The MAPs were significantly higher in the GA group compared with those in the EA and SA groups $(\mathrm{p}<0.05)$. The MAP recorded after the induction of SA was significantly lower than that of the EA group (91.0 $\pm 14.1,77.5 \pm 14.5$, respectively) $(\mathrm{p}=0.000) . \mathrm{SpO}_{2}$ levels were significantly lower in the GA group compared with those in the EA and SA groups, but the values were in the normal range $(\mathrm{p}<0.05)$ (Table 2$)$.

The total amount of iv fluid given to patients was lower in the GA group $(1180 \pm 284 \mathrm{~mL})$ compared with those in the SA group $(1480 \pm 420 \mathrm{~mL})$ and EA group $(1528 \pm 386 \mathrm{~mL})$. The SA and EA groups were similar regarding the total amount of iv fluid given. Total blood loss was higher in the GA group than in the other study groups $(\mathrm{p}<0.05)$. Seven parturient females in the EA group and 12 parturient females in the SA group needed iv ephedrine. The mean ephedrine requirement was $10 \mathrm{mg}$ in both groups.
The maternal mobilisation time was longer in the GA and EA groups compared with that in the SA group $(\mathrm{p}<0.05)$. The first defaecation time was significantly prolonged in the GA group $(34.2 \pm 1.2 \mathrm{~h})$, and the shortest time was recorded in the EA group $(26.0 \pm 4.1 \mathrm{~h})(\mathrm{p}=0.000)$. The discharge of patients was similar among the study groups (Table 1 ).

The time to the first analgesic requirement was significantly longer in the EA group $(390 \pm 28.3 \mathrm{~min})(\mathrm{p}=0.000)$ (Table 1).

Although the time intervals for the skin-uterine incision were comparable in the study groups, the time interval for the uterineincision delivery was longer in the GA group $(2.0 \pm 1.2 \mathrm{~min})$ than in the EA group $(1.6 \pm 1.0 \mathrm{~min})$ and $\mathrm{SA}$ group $(1.0 \pm 0.7 \mathrm{~min})$ $(\mathrm{p}<0.05)$.

The Apgar scores of newborns were significantly lower at the $1^{\text {st }}$, $5^{\text {th }}$ and $10^{\text {th }}$ minute in the GA group than in the other groups $(\mathrm{p}<0.05)$, and were comparable in the EA and SA groups. The $\mathrm{SpO}_{2}$ values of newborns were lower in the GA group than in the EA and SA groups $(\mathrm{p}<0.05)$. Six newborns required a free $\mathrm{O}_{2}$ supply and PPV, and one newborn from the GA group was intubated and transferred to the neonatal intensive care unit (NICU). Neither of the newborns delivered in the EA or SA groups required these intentions. The blood gas analysis of blood from the umbilical vein of the newborns produced similar results for the three study groups. (Table 3)

The postnatal 48-hour weight loss of the newborn was higher in the EA group $(5.6 \% \pm 2.5 \%)$ and SA group $(5.7 \% \pm 2.2 \%)$ than in the GA group $(4.0 \pm 2.0)(\mathrm{p}<0.05)$. All three study groups were comparable regarding plasma bilirubin levels at postnatal 24 and 48 hours and hypoglycaemia incidence at postnatal 24 hours. No newborn had phototherapy requirements (Table 3).

The first breastfeeding time differed among the study groups. The newborns in the GA group were breastfed $2.9 \pm 0.9$ hours after delivery, which was significantly later than the times in the EA and SA groups $(\mathrm{p}<0.05)$. The first breastfeeding time was similar in the EA $(2.1 \pm 0.3 \mathrm{~h})$ and SA $(2.2 \pm 0.4 \mathrm{~h})$ groups ( $>0.05)$ (Table 2).

Table 1. Maternal parameters

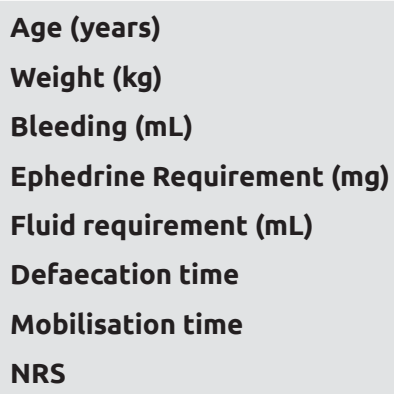

First analgesic requirement (minute)

$28.4 \pm 4.3$
$78.9 \pm 11.5$
$736.6 \pm 163.7$
0
$1,180 \pm 284$
$34.2 \pm 1.2$
$7.2 \pm 1.1$
$3.84 \pm 0.8$

$35.0 \pm 9.5$
EA

$28.6 \pm 4.1$

$73.0 \pm 10.9$

$350 \pm 108.0$

70

$1,480 \pm 420$

$26.0 \pm 4.1$

$7.1 \pm 0.5$

$0.44 \pm 0.65$

$390 \pm 28.3$

\section{SA}

$29.7 \pm 4.4$

$77.0 \pm 12.7$

$344 \pm 92.8$

120

$1528 \pm 386$

$28.5 \pm 1.0$

$5.9 \pm 1.0$

$0.64 \pm 0.76$

$230 \pm 35.7$
P

0.493

0.207

0.000

0.000

0.003

0.000

0.000

0.000

0.000

GA: General anaesthesia, EA: Epidural anaesthesia, SA: Spinal anaesthesia 
Orhon Ergün et al. Anesthesia for Cesarean and Clinical Effects

Table 2. Maternal mean arterial pressure and $\mathrm{SpO} 2$ values

\begin{tabular}{|c|c|c|c|c|}
\hline MAP (mmHg) & GA & EA & SA & $P$ \\
\hline 0 minute & $104.0 \pm 13.8$ & $102.2 \pm 12.7$ & $98.2 \pm 10.5$ & 0.02 \\
\hline Induction & $108.0 \pm 16.6$ & $91.0 \pm 14.1$ & $77.5 \pm 14.5$ & 0.000 \\
\hline Incision $1^{\text {st }}$ minute & $114.0 \pm 14.3$ & $85.1 \pm 15.4$ & $77.6 \pm 14.4$ & 0.000 \\
\hline Incision $5^{\text {th }}$ minute & $107.8 \pm 17.4$ & $85.0 \pm 10.4$ & $81.9 \pm 12.2$ & 0.000 \\
\hline Incision $10^{\text {th }}$ minute & $95.6 \pm 20.4$ & $84.8 \pm 9.3$ & $79.3 \pm 9.3$ & 0.002 \\
\hline Incision $20^{\text {th }}$ minute & $88.0 \pm 16.2$ & $77.9 \pm 9.3$ & $73.2 \pm 7.1$ & 0.000 \\
\hline Incision $40^{\text {th }}$ minute & $104.5 \pm 11.3$ & $73.0 \pm 6.5$ & $72.4 \pm 7.8$ & 0.000 \\
\hline \multicolumn{5}{|l|}{$\mathrm{SpO}_{2}$} \\
\hline 0 minute & $98.9 \pm 1.2$ & $99.0 \pm 0.7$ & $99.0 \pm 0.9$ & 0.001 \\
\hline Induction & $98.9 \pm 0.7$ & $99.7 \pm 0.7$ & $99.5 \pm 0.6$ & 0.000 \\
\hline Incision $1^{\text {st }}$ minute & $98.6 \pm 1.2$ & $99.8 \pm 0.5$ & $99.5 \pm 0.6$ & 0.000 \\
\hline Incision $5^{\text {th }}$ minute & $98.7 \pm 0.9$ & $99.8 \pm 0.4$ & $99.4 \pm 0.7$ & 0.000 \\
\hline Incision $10^{\text {th }}$ minute & $98.3 \pm 0.9$ & $99.8 \pm 0.5$ & $99.4 \pm 0.7$ & 0.000 \\
\hline Incision $20^{\text {th }}$ minute & $98.1 \pm 0.9$ & $99.7 \pm 0.5$ & $99.4 \pm 0.6$ & 0.000 \\
\hline Incision $40^{\text {th }}$ minute & $98.7 \pm 0.7$ & $99.8 \pm 0.4$ & $99.4 \pm 0.6$ & 0.000 \\
\hline
\end{tabular}

GA: General anaesthesia, EA: Epidural anaesthesia, SA: Spinal anaesthesia

Table 3. Postpartum assessment parameters of the newborns

\begin{tabular}{|c|c|c|c|c|}
\hline & $\begin{array}{l}G A(n=25) \\
\text { Mean } \pm \text { SD }\end{array}$ & $\begin{array}{l}\text { EA }(n=25) \\
\text { Mean } \pm \text { SD }\end{array}$ & $\begin{array}{l}\text { SA }(n=25) \\
\text { Mean } \pm \text { SD }\end{array}$ & $\mathrm{p}$ \\
\hline \multicolumn{5}{|l|}{ Apgar Score } \\
\hline $1^{\text {st }}$ minute & $7.6 \pm 1.4$ & $8.9 \pm 0.3$ & $9.0 \pm 0.3$ & 0.000 \\
\hline $5^{\text {th }}$ minute & $9.0 \pm 0.9$ & $9.8 \pm 0.4$ & $9.9 \pm 0.3$ & 0.000 \\
\hline $10^{\text {th }}$ minute & $9.8 \pm 0.4$ & $10.0 \pm 0.0$ & $10.0 \pm 0.0$ & 0.015 \\
\hline \multicolumn{5}{|l|}{$\mathrm{SPO}_{2}$} \\
\hline $5^{\text {th }}$ minute & $85.3 \pm 3.8$ & $94.2 \pm 1.9$ & $94.4 \pm 1.7$ & 0.000 \\
\hline $10^{\text {th }}$ minute & $91.4 \pm 4.0$ & $97.0 \pm 1.6$ & $97.0 \pm 1.3$ & 0.000 \\
\hline $30^{\text {th }}$ minute & $97.8 \pm 1.4$ & $99.1 \pm 1.4$ & $99.3 \pm 1.0$ & 0.000 \\
\hline \multicolumn{5}{|l|}{ Blood gas analysis } \\
\hline $\mathrm{Ph}$ & $7.3 \pm 0.0$ & $7.3 \pm 0.0$ & $7.3 \pm 0.0$ & 0.052 \\
\hline $\mathrm{HCO}_{3}$ & $24.8 \pm 1.7$ & $24.3 \pm 1.9$ & $23.8 \pm 2.4$ & 0.246 \\
\hline Phototherapy (yes/no) & $0 / 25$ & $0 / 25$ & $0 / 25$ & - \\
\hline \multicolumn{5}{|l|}{ Bilirubin (mg/dL) } \\
\hline 24 hours & $4.0 \pm 1.9$ & $3.8 \pm 1.5$ & $3.2 \pm 1.4$ & 0.198 \\
\hline 48 hours & $5.2 \pm 2.3$ & $4.9 \pm 1.5$ & $5.0 \pm 2.2$ & 0.915 \\
\hline \multicolumn{5}{|l|}{ Postnatal weight loss (\%) } \\
\hline 24 hours & $3.3 \pm 1.4$ & $3.8 \pm 1.4$ & $3.8 \pm 1.0$ & 0.260 \\
\hline 48 hours & $4.0 \pm 2.0$ & $5.6 \pm 2.5$ & $5.7 \pm 2.2$ & 0.630 \\
\hline Hypoglycaemia 24 hours (yes/no) & $0 / 25$ & $0 / 25$ & $0 / 25$ & - \\
\hline Requirement of Free oxygen & 6 & 0 & 0 & 0.001 \\
\hline
\end{tabular}




\section{Discussion}

This prospective randomised study compared the maternal and foetal effects of different anaesthesia techniques during caesarean delivery. The newborns had lower Apgar scores, often required free $\mathrm{O}_{2}$ supply and PPV and had a longer time to first breastfeeding when GA was performed. The recovery of the mothers' bowel functions occurred earliest in the EA group.

General and regional anaesthesia techniques for caesarean delivery have both advantages and disadvantages. Studies conducted to date have researched the effects of the anaesthesia method on mothers, and neuraxial anaesthesia techniques have become the preferred method for supporting maternal safety. However, there remains controversy about their effects on newborns.

The most significant adverse effect of regional anaesthesia, which also directly affects the foetus, is perioperative hypotension. Maternal hypotension related to sympathetic block is the most common complication of regional anaesthesia. The incidence of maternal hypotension has been reported to be 39\% in EA and $48 \%$ in SA (12). As uterine blood pressure depends upon perfusion pressure, severe hypotension may lead to foetal acidosis and neonatal depression or maternal nausea and vomiting by decreasing uterine and intervillous blood flow (13). In a previous study conducted on umbilical cord arterial $\mathrm{pH}$ and the Apgar scores of newborns, hypotension due to SA did not lead to any change in neonatal Apgar scores and blood $\mathrm{pH}$ when treated immediately (14). In our study, arterial blood pressure values were lower in the EA and SA groups than in the GA group. The pre-incision blood pressure level of the SA group was lower than that of the EA group, and the ephedrine requirement of the SA group was higher than that of the other groups. Although early development of hypotension in the SA group and its requirement for higher doses of ephedrine is a disadvantage, this does not reveal a negative clinical consequence, as the newborns' Apgar scores and $\mathrm{SpO}_{2}$ values were higher in the SA group than in the GA group. In addition, there was no difference in the newborns' blood gas analysis values.

There is no specific data on the superiority of one method versus another regarding the prevention and treatment of hypotension that develops during a caesarean section (15). The effectiveness of preoperative fluid loading for the prevention of maternal hypotension during regional anaesthesia remains a controversial issue. In this study, we determined the amount of iv fluid given according to haemodynamic data without any preloading, and the amount was found to be significantly higher in patients receiving epidural and SA. This may have resulted because GA has less of an effect on the sympathetic nervous system, resulting in vasodilation.

The studies comparing GA and regional anaesthesia regarding perioperative bleeding in caesarean section procedures had conflicting results. Even if the bleeding was high in GA, there was no need for blood transfusion $(16,17)$. Similarly, in our study, the amount of bleeding in the GA group was significantly higher compared with that in the other groups, and no patient required blood transfusions.
Most studies considering the effects of different anaesthesia methods on newborns do not include detailed information, such as skin incision-uterine incision time and time of delivery. Kamat et al. (18) analysed the influence of time to induction-delivery and uterine-incision delivery on Apgar scores. They concluded that intervals are shorter in the GA group compared with those in the SA group (57 vs 68 seconds, respectively). Nevertheless, Steinbrook et al. (19) reported that the time between uterine incision and delivery was longer in the GA group compared with that in the SA group (59 vs 45 seconds, respectively). In our study that included more data, the interval between the skin and uterine incision was similar between groups; however, the interval between uterine incision and delivery was shorter in the SA group. This finding may have resulted because of the more intense motor block during SA.

Spinal and EA techniques are known to provide earlier recovery of bowel function during the postoperative period (20). Sympathetic block plays a significant role in the recovery of bowel function. The parasympathetic system is activated and increases the motility in the stomach, small intestine and proximal colon. Another reason for the delayed recovery of bowel function in patients operated under GA may be late oral intake after GA (19). In this study, the time to the first defaecation was significantly shorter in the EA group but significantly prolonged in the GA group.

In Solangi et al.'s (21) study that evaluated the effect of anaesthesia on newborns, the Apgar scores of newborns at the $1^{\text {st }}$ and $5^{\text {th }}$ minute in the SA group were higher than those in the GA group. Kavak et al. (22) reported that Apgar scores were similar in the EA and SA groups at both the $1^{\text {st }}$ and $5^{\text {th }}$ min. Similarly, in our study, the scores measured at the $1^{\text {st }}, 5^{\text {th }}$ and $10^{\text {th }}$ minutes were higher in the SA and EA groups compared with those in the GA group. A significant number of newborns in the GA group required a free $\mathrm{O}_{2}$ supply and PPV. Longer exposure to inhalational agents during GA may have caused decreased Apgar scores in newborns. As the baby delivery time was under three minutes in all three groups and inhalational agents were not administered during the interval between bladder retractor and umbilical cord clamping in the GA group, no acidosis was observed in the present study. However, other studies state that umbilical cord $\mathrm{pH}$ values of the newborn were different in general and regional anaesthesia (23). Yegin et al. (24) reported that maternal hypotension develops as a result of regional anaesthesia decreases uteroplacental perfusion and causes foetal acidosis. These results have shown the significance of the prevention or treatment of maternal hypotension during caesarean section.

The correlation between regional anaesthesia and breastfeeding has not been clearly identified because of the limitations of previous studies. Although several studies indicated that epidural anaesthesia does not affect postnatal milk release and the success of breastfeeding $(25,26)$, Szabo (27) reported that the duration and frequency of breastfeeding in the EA group were higher than in the GA group. In our study, the time to first breastfeeding was prolonged in the GA group and was nearly one hour longer than that in the SA and EA groups. A longer length of recovery room 
stay may have caused this result. The World Health Organization (WHO) advises that newborns should start breastfeeding within one hour of birth (28).

Fluid loading to prevent hypotension during epidural and SA leads to infusion of fluid into the foetus through the placenta and increases the volume of foetal extracellular fluid. This may result in excessive weight loss during the first days of life. In this study, we administered more iv fluid to control maternal hypotension. We believe that the administration of excessive fluid loading to prevent hypotension led to more weight loss in newborns in the SA and EA groups at the $48^{\text {th }}$ hour.

In the present study, the incidence of early hypoglycaemia and the need for phototherapy in neonates were similar among the groups. In addition, Tonni et al. (29) reported that the hypoglycaemia incidence was similar in the infants of patients undergoing spinal and GA. Several studies have suggested that epidural and SA techniques are superior to GA regarding neonatal hyperbilirubinemia but do not increase the need for phototherapy $(30,31)$. In our study, no neonates developed hypoglycaemia or required phototherapy.

\section{Conclusion}

We concluded that GA might lead to lower Apgar scores, a more frequent requirement for a free $\mathrm{O}_{2}$ supply and PPV, and a longer time to first breastfeeding than spinal and EA. Therefore, regional anaesthesia techniques should be preferred to caesarean delivery with less negative clinical consequences on newborns.

\section{Ethics}

Ethics Committee Approval: The Ethics Committee approved the study (B104ISM4340029-1009-90) and written informed consent was obtained.

Informed Consent: Obtained.

Peer-review: Externally and internally peer reviewed.

\section{Authorship Contributions}

Concept: M.O.E., E.Z.E., K.T.S., A.M., E.M., Design: M.O.E., E.Z.E., K.T.S., A.M., E.M., Data Collection or Processing: M.O.E., E.Z.E., K.T.S., A.M., E.M., Analysis or Interpretation: M.O.E., E.Z.E., K.T.S., A.M., E.M., Literature Search: M.O.E., E.Z.E., K.T.S., A.M., E.M., Writing: M.O.E., E.Z.E., K.T.S., A.M., E.M.

Conflict of Interest: No conflict of interest was declared by the authors.

Financial Disclosure: The authors declared that this study received no financial support.

\section{References}

1. Lesage S. Cesarean delivery under general anesthesia: continuing professional development. Can J Anaesth 2014;61:489-503.

2. Yamashita A, Irikoma S. Comparison of inflationary non-invasive blood pressure (iNIBP) monitoring technology and conventional deflationary non-invasive blood pressure (dNIBP) measurement in detecting hypotension during cesarean section. JA Clin Rep 2018;4:5.

3. Malin GL, Morris RK, Khan KS. Strength of association between umbilical cord $\mathrm{pH}$ and perinatal and long term outcomes: systematic review and meta-analysis. BMJ 2010;340:c1471.

4. Jain K, Makkar JK, Subramani Vp S, Gander S, Kumar P. A randomized trial comparing prophylactic phenylephrine and ephedrine infusion during spinal anesthesia for emergency cesarean delivery in cases of acute fetal compromise. J Clin Anesth 2016;34:208-15.

5. MardirosoffC, Dumont L, Boulvain M, Tramer MR. Fetal bradycardia due to intrathecal opioids for labour analgesia: a systematic review. BJOG 2002;109:274-81.

6. Hattler J, Klimek M, Rossaint R, Heesen M. The effect of combined spinal-epidural versus epidural analgesia in laboring women on nonreassuring fetal heart rate tracings: systematic review and metaanalysis. Anesth Analg 2016;123:955-64.

7. Hess PE. What's new in clinical obstetric anesthesia in 2015? Int J Obstet Anesth 2017;32:54-63.

8. Strouch ZY, Dakik CG, White WD, Habib AS. Anesthetic technique for cesarean delivery and neonatal acid-base status: a retrospective database analysis. Int J Obstet Anesth 2015;24:22-9.

9. Ikonomidou C, Bosch F, Miksa M, Bittigau P, Vockler J, Dikranian K, et al. Blockade of NMDA receptors and apoptotic neurodegeneration in the developing brain. Science 1999;283:70-4.

10. Jevtovic-Todorovic V, Hartman RE, Izumi Y, Benshoff ND, Dikranian $\mathrm{K}$, Zorumski CF, et al. Early exposure to common anesthetic agents causes widespread neurodegeneration in the developing rat brain and persistent learning deficits. J Neurosci 2003;23:876-82.

11. Popic J, Pesic V, Milanovic D, Loncarevic-Vasiljkovic N, Smiljanic $\mathrm{K}$, Kanazir S, et al. Induction of TNF-alpha signaling cascade in neonatal rat brain during propofol anesthesia. Int J Dev Neurosci 2015;44:22-32.

12. Clark RB. Hypotension and caesarean section. $\mathrm{Br} \mathrm{J}$ Anaesth 2008;101:882-3.

13. Afolabi BB, Lesi FEA. Regional versus general anaesthesia for caesarean section. Cochrane Database Syst Rev 2012;10:CD004350.

14. Nishikawa K, Yokoyama N, Saito S, Goto F. Comparison of effects of rapid colloid loading before and after spinal anesthesia on maternal hemodynamics and neonatal outcomes in cesarean section. J Clin Monit Comput 2007;21:125-9.

15. Morgan PJ, Halpern SH, Tarshis J. The effects of an increase of central blood volume before spinal anesthesia for cesarean delivery: a qualitative systematic review. Anesth Analg 2001;92:997-1005.

16. Lertakyamanee J, Chinachoti T, Tritrakarn T, Muangkasem J, Somboonnanonda A, Kolatat T. Comparison of general and regional anesthesia for cesarean section: success rate, blood loss and satisfaction from a randomized trial. J Med Assoc Thai 1999;82:672-80.

17. Aly HA, Ramadani HM. Assessment of blood loss during cesarean section under general anesthesia and epidural analgesia using different methods. AJAIC 2006;9:25-34.

18. Kamat SK, Shah MV, Chaudhary LS, Pandya S, Bhatt MM. Effect of induction-delivery and uterine-delivery on apgar scoring of the newborn. J Postgrad Med 1991;37:125-7. 
19. Steinbrook RA. Epidural anesthesia and gastrointestinal motility. Anesth Analg 1998;86:837-44.

20. Fotiadis RJ, Badvie S, Weston MD, Allen-Mersh TG. Epidural analgesia in gastrointestinal surgery. Br J Surg 2004;91:828-41.

21. Solangi SA, Siddiqui SM, Khaskheli MS, Siddiqui MA. Comparison of the effect of general and spinal anesthesia on neonatal outcome. Anaesth Pain Intensive Care 2012;16:18-23.

22. Kavak ZN, Basgul A, Ceyhan N. Short-term outcome of newborn infants: spinal versus general anesthesia for elective cesarean section. A prospective randomized study. Eur J Obstet Gynecol Reprod Biol 2001;100:50-4.

23. Petropoulos G, Siristatidis C, Salamalekis E, Creatsas G. Spinal and epidural versus general anesthesia for elective cesarean section at term: effect on the acid-base status of the mother and newborn. J Matern Fetal Neonatal Med 2003;13:260-6.

24. Yeğin A, Ertuğ Z, Yılmaz M, Erman M. The effects of epidural anesthesia and general anesthesia on newborns at cesarean section. Türk J Med Sci 2003;33:311-4.

25. Wiklund I, Norman M, Uvnas-Moberg K, Ransjo-Arvidson AB, Andolf E. Epidural analgesia: breast-feeding success and related factors. Midwifery 2009;25:e31-8.

26. Wilson MJ, MacArthur C, Cooper GM, Bick D, Moore PA, Shennan A. Epidural analgesia and breastfeeding: a randomised controlled trial of epidural techniques with and without fentanyl and a non-epidural comparison group. Anaesthesia 2010;65:145-53.

27. Szabo AL. Intrapartum neuraxial analgesia and breastfeeding outcomes: limitations of current knowledge. Anesth Analg 2013;116:399-405.

28. WHO. Pregnancy, childbirth, postpartum and newborn care: a guide for essential practice. 3rd ed. Geneva, Switzerland. 2015. Available from: URL: https://apps.who. int/iris/bitstream/handle/10665/249580/9789241549356eng.pdf; jsessionid $=4 \mathrm{C} 00762 \mathrm{DE} 3 \quad \mathrm{DA} 9 \mathrm{~B} 38 \mathrm{~B} 4 \quad 69 \mathrm{DF} 10$ $50 \mathrm{~F} 2 \mathrm{FEB} 3$ ? sequence $=1$

29. Tonni G, Ferrari B, De Felice C, Ventura A. Fetal acid-base and neonatal status after general and neuraxial anesthesia for elective cesarean section. Int J Gynaecol Obstet 2007;97:143-6.

30. Ozcakir HT, Lacin S, Baytur YB, Luleci N, Inceboz US. Different anesthesiologic strategies have no effect on neonatal jaundice. Arch Gynecol Obstet 2004;270:179-81.

31. Demiraran Y, Albayrak M, Seker IS, Kaynak G, Iskender A, Sezen GY, et al. Effect of anesthesiological strategies on neonatal bilirubin levels during cesarean section: a prospective and randomized trial. Arch Gynecol Obstet 2011;284:1059-65. 